\title{
Penerapan Pompa Tanpa Listrik (Heron's Fountain) untuk Hidroponik DFT (Deep Flow Technique) di Kelurahan Sukamerindu Kecamatan Sungai Serut Kota Bengkulu
}

\author{
Nanang Sugianto ${ }^{1}$, Irkhos' ${ }^{2}$, Supiyati², Helfi Eka Saputra ${ }^{2}$ \\ 1,2 Universitas Bengkulu, Indonesia
}

\begin{abstract}
A B S T R A C T
THE APPLICATION OF NON-ELECTRIC PUMP (HERON'S FOUNTAIN) FOR DFT HYDROPONIC (DEEP FLOW TECHNIQUE) IN SUKAMERINDU, SUNGAI SERUT, BENGKULU CITY. Science and technology-based community engagement about the application of non-electric pump (Heron's Fountain) for DFT hydroponics (Deep Flow Technique) have been carried out for mother group (respondent) in Sukamerindu, Sungai Serut, Bengkulu City. The aim of this activity is to apply the Appropriate Technology like hydroponics and Heron's Fountain pumps. The methods of this activities are carried out by training which include socialization and field practice. This program produces 5 hydroponics which are equipped with Heron's Fountain pumps and brief guidebook about of technologies. The application of the Heron's Fountain pump for DFT hydroponics was effective in circulating nutrients for hydroponic plants. The Heron's Fountain pump works temporarily for 45 minutes (10 liters). It was considered sufficient to circulate nutrients for hydroponic plants as evidenced by the same quality for all plants. All plants grow optimally and more yields than initial estimates. The planting period to harvest using hydroponic technology and the Heron's Fountain pump is quite short, which is approximately 2.5 months. The use of these two technologies helps partners to start farming without using soil media. The cost of making and operating both systems so as to increase the interest of respondent to implement them independently.

Keywords: Effective, Heron's Fountain Pump, Hydroponics, Inexpensive.

\begin{tabular}{llll}
\hline Received: & Revised: & Accepted: & Available online: \\
14.10 .2019 & 07.11 .2019 & 03.02 .2020 & 14.02 .2020 \\
\hline
\end{tabular}
\end{abstract}

\section{Suggested citation:}

Sugianto, N., Irkhos., Supiyati., \& Saputra, H. (2020). Penerapan pompa tanpa listrik (Heron's Fountain) untuk hidroponik DFT (Deep flow technique) di Kelurahan Sukamerindu Kecamatan Sungai Serut Kota Bengkulu. Jurnal Pengabdian Pada Masyarakat, 5(1), 59-70. https://doi.org/10.30653/002.202051.248

Open Access I URL: http://ppm.ejournal.id/index.php/pengabdian/article/view/248

\footnotetext{
1 Corresponding Author: Program Studi Geofisika, FMIPA Universitas Bengkulu; Jl. WR. Supratman, Kandang Limun, Muara Bangka Hulu, Kota Bengkulu, Bengkulu, Indonesia; Email: nanang.s@unib.ac.id dan nanangsugiantosugi@gmail.com
} 


\section{PENDAHULUAN}

Kota Bengkulu merupakan Kabupaten/Kota yang memiliki kepadatan penduduk tertinggi di Provinsi Bengkulu (BPS, 2013). Jumlah penduduk tertinggi ini diikuti dengan daya konsumsi masyarakat yang tinggi terhadap hasil tanaman hortikultura seperti sayur-sayuran. Ketersediaan sayur-sayuran di kota Bengkulu umumnya dipasok dari luar daerah yaitu Kabupaten Rejang Lebong (BPS, 2013). Panjangnya rantai distribusi dari perkebunan hingga ke tangan konsumen membuat harga sayursayuran di pasar tradisional maupun di pasar modern naik berlipat ganda. Kondisi ini tak jarang menjadi keluhan bagi sebagian pembeli karena selain harga sayuran yang cukup mahal, kondisi sayuran juga sudah tidak segar. Beberapa masyarakat Kota Bengkulu mengeluh dan meyikapi kondisi ini dengan menanam tanaman hortikultura secara mandiri di pekarangan rumah menggunakan media polibek (Gambar 1) seperti yang dilakukan oleh ibu-ibu PKK RT. 12, Kelurahan Sukamerindu, Kecamatan Sungai Serut, Kota Bengkulu. Teknik menanam menggunakan media polibek dipilih karena tanah di pekarangan merupakan tanah lempung (liat) berwarna oranye yang tidak maksimal untuk jadikan sebagai media tanam langsung tanaman hortikultura.

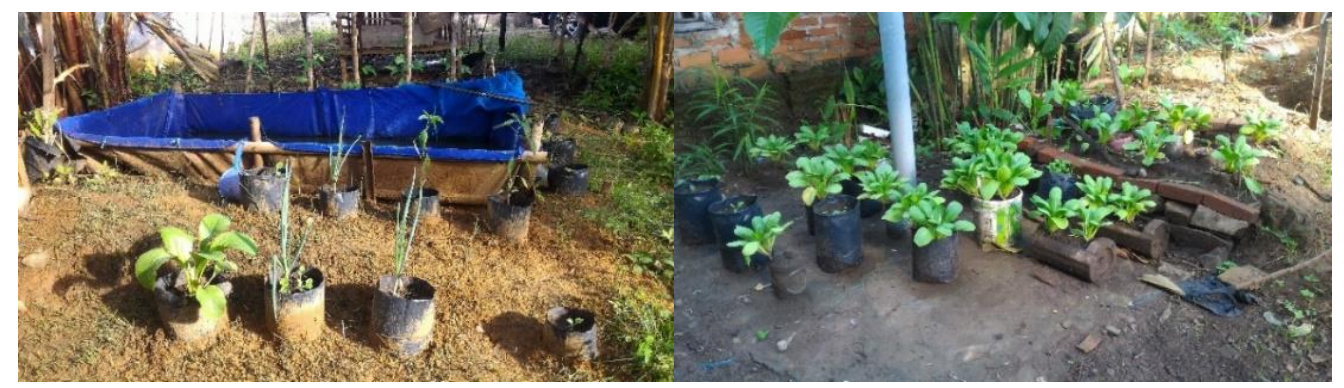

Gambar 1. Penggunaan polibek untuk media tanam tanaman hortikultura (sayuran berdasarkan pengamatan visual secara langsung

Ibu-ibu PKK RT. 12, RW. 001 Kelurahan Sukamerindu Kecamatan Sungai Serut Kota Bengkulu merupakan khalayak sasaran atau mitra dalam kegiatan program pengabdian kepada masyarakat berbasis IPTEKS tahun 2018 ini. Luas rata-rata pekarangan warga di RT. 12, RW. 001 Kelurahan Sukamerindu Kecamatan Sungai Serut Kota Bengkulu adalah $6 \mathrm{~m}^{2}(2 \mathrm{~m} \times 3 \mathrm{~m})$. Meskipun teknik tanam menggunakan polibek ini dipilih untuk memanam tanaman hortikultura, beberapa kekurangan juga dirasakan oleh ibu PKK ini diantaranya kesulitan mendapatkan tanah yang bagus, tetap membutuhkan lahan yang cukup luas dan membutuhkan dana yang banyak untuk pengadaan atau pembelian tanah kompos.

Teknologi tepat guna (TTG) yang disepakati bersama antara tim pengabdian dengan mitra untuk mengatasi permasalahan keterbatasan luas lahan (Roidah, 2014) dan keterbatasan biaya operasional bagi mitra dalam bercocok tanam tanaman hortikultura adalah dengan menerapkan teknologi hidroponik DFT (Deeep flow Technique) non listrik. Hidroponik DFT adalah teknologi menanam tanaman hortikultura tanpa menggunakan media tanah melainkan media air yang diberi nutrisi. Prinsip kerja hidroponik DFT adalah mensirkulasikan larutan nutrisi dan aerasi secara kontinyu atau terus-menerus (Anas, 2013; Atmaja, 2009). Upaya menekan biaya operasional pada penggunaan hidropnik jenis DFT juga dapat dilakukan dengan 
sirkulasi nutrisi terputus (Iqbal, 2006). Tanaman dianggap masih hidup sehat pada larutan nutrisi dengan oksigen terlarut minimal $4 \mathrm{mg} / \mathrm{l}$ (Purnomo, 2006). Hasil lain juga menunjukkan bahwa pengaruh aeresi terhadap pertumbuhan dan hasil tanaman hortikultura masih optimal (tidak berbeda dengan aeresi non-stop) pada sirkulasi menyala selama 15 menit dan mati selama 60 menit (Ningrum dkk, 2014). Teknologi hidroponik DFT non listrik adalah penggabungan teknologi hidroponik DFT dan teknologi pompa Heron's Fountain yang menerapkan sirkulasi nutrisi dan aeresi terputus. Terpenting dari teknologi hidroponik DFT non listrik adalah pemanfaaatn pompa Heron's Fountain sabagai alat untuk mensirkulasikan nutrisi dan aeresi tanaman hidroponik tanpa menggunakan energi listrik sebagai upaya tambahan dalam menekan biaya operasional. Pompa Heron's Fountain merupakan alat pemompa air seperti halnya pompa air biasa untuk hidroponik hanya saja tidak menggunakan energi listrik, melainkan memanfaatkan tekanan fluida yang bergerak secara kontinu pada sistemnya. Prinsip kerja pompa Heron's Fountain didasari oleh gaya gravitasi, massa jenis fluida dan tekanan. Cara kerja sistem seperti hukum Bernoulli dimana terjadi tekanan dan gaya konstanta pada masukan dan luaran (Kezerashvili dan Sapozhnikov, 2016). Secara fisika, hubungan matematika yang menjelaskan pompa Heron's Fountain diberikan oleh Georgescu dkk (2013) pada (1).

$$
\Delta p=\left(\rho_{\text {air }}-\rho_{\text {udara }}\right) g h_{\text {udara }}(1)
$$

$\Delta p$ adalah perbedaan tekanan air dan udara, $\rho_{\text {air }}=$ densitas air, $\rho_{\text {udara }}=$ densitas udara, $g=$ percepatan gravitasi dan $h_{\text {udara }}=$ ketinggian permukaan air atas dan air bagian selang bawah. Ilustrasi penerapan pompa Heron's Fountain ditunjukkan pada Gambar 2a, sedangkan wujud modifikasi pompa Heron's Fountain yang dibuat ditunjukkan pada Gambar 2b.

(a)

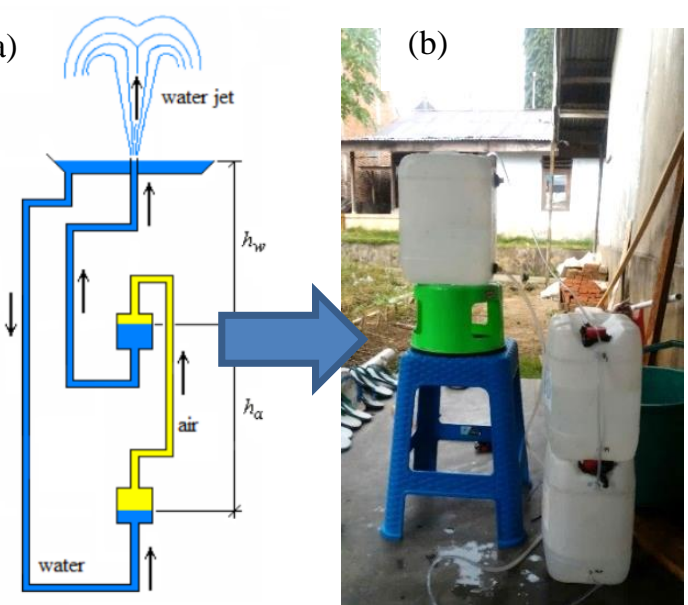

Gambar 2. (a) Skema pompa Heron's fountain tanpa menggunakan energi listrik (Georgescu dkk, 2013); (b) Wujud modifikasi pompa Heron's Fountain berdasarkan uji coba sistem yang pernah dilakukan menggunakan dirigen

Dua teknologi ini merupakan pengetahuan baru bagi pihak mitra mulai dari cara membuat, cara menggunakan dan cara menerapkannya, sehingga pihak mitra belum mengetahui efektifitas dua teknologi ini dalam memproduksi tanaman hortikultura. Berdasarkan uraian permasalahan yang dihadapi, tim pengabdian masyarakat 
Universitas Bengkulu bekerja sama dengan mitra melalui program PPM berbasis IPTEK dalam mewujudkan kegiatan pemberdayaan masyarakat melalui penerapan teknologi hidroponik dan pompa Heron's Fountain untuk tanaman hortikultura. Kegiatan PPM ini juga bertujuan untuk membentuk kelompok usaha tanaman hortikultura bagi Ibu-ibu PKK RT. 12, RW. 001, Kelurahan Sukamerindu Kecamatan Sungai serut Kota Bengkulu menggunakan teknologi hidrponik DFT non listrik. Kegiatan pengabdian ini diharapkan menjadi salah satu alternatif bagi mitra yang memiliki minat tinggi terhadap bercocok tanam tetapi memiliki keterbatasan luas pekarangan dan biaya operasional serta bernilai ekonomis bagi mitra.

\section{METODE}

\section{Pendekatan}

Berdasarkan hasil diskusi bersama khalayak sasaran, program pengabdian masyarakat ini dilakukan dengan pendekatan partisipatif yang menerapkan setidaknya empat metode antara lain metode pendidikan (penyuluhan), pelatihan dan metode subtitusi dan difusi IPTEKS. Semua metode ini menitik-beratkan pada keterlibatan langsung khalayak sasaran dalam merancang, membuat dan menerapkan sistem hidroponik dan pompa Heron's Fountain untuk menanam tanaman hortikultura. Lokasi kegiatan PPM ini dilakukan di rumah dan halaman kediaman salah satu anggota Ibu PKK yang beralamat di Jalan Jawa 2, No.11, RT.12, Kelurahan Sukamerindu, Sungai Serut, Kota Bengkulu. Pemecahan masalah secara operasional adalah sebagai berikut: 1) memberikan Pendidikan mengenai hidroponik DFT dan pompa tanpa listrik (Pompa Heron's Fountain), 2) memberikan pendidikan dan pelatihan tentang penggabungan teknologi hidroponik DFT dan pompa Heron's Fountain menjadi teknologi hidroponik DFT non listrik, 3) memberikan pendampingan dalam membuat bangun dan penggunaan hidroponik DFT non listrik, 4) memberikan pelatihan dan pendampingan teknik menyemai, menanam, merawat dan memanen tanaman hortikultura pada sistem hidroponik DFT dan 5) memberikan pendampingan kepada mitra untuk melakukan analisis nilai ekonomis dari penerapan teknologi serta pendampingan pembentukan kelompok usaha tani tanaman hortikultura. Prosedur kegiatan dilakukan dua sesi, yaitu sesi kelas dan sesi lapangan seperti yang dijelaskan secara rinci pada bagian prosedur kegiatan.

\section{Prosedur Kegiatan}

Upaya realisasi pelaksanaan program PPM berbasis IPTEKS ini di lakukan dalam bentuk pelatihan dan penerapan ipteks. Kegiatan pelatihan dilakukan pada sesi kelas sedangkan penerapan ipteks dilakukan pada sesi lapangan. Prosedur yang dilalui pada pelaksanaan kegiatan meliputi tahapan sebagai berikut:

Tahapan pertama adalah tahap persiapan. Kegiatan yang dilakukan pada tahap persiapan meliputi koordinasi tim pengabdian Universitas Bengkulu dengan khalayak sasaran pengabdian berupa pengurusan perizinan di Kelurahan Sukamerindu Kecamatan Sungai Serut kota Bengkulu khususnya kepada Ibu-ibu PKK RT. 12 RW. 001, penyusunan rencana dan jadwal kegiatan serta dilakukan pembagian tugas kerja 
anggota tim. Selain koordinasi kepada khalayak sasaran, pada tahap persiapan juga dilakukan pengumpulan peralatan dan bahan yang akan digunakan selama kegiatan PPM berlangsung seperti pengadaan 1 set Bor listrik, pengadaan alat lem tembak plastik, pengadaan bahan-bahan untuk membuat alat hidroponik dan pompa Heron's Fountain seperti paralon berbagai ukuran, selang kecil, lem dan sebagainya. Pada tahap ini juga dilakukan pengadaan media tanam pada sistem hidroponik, pupuk untuk nutrisi tanaman dan bibit beberapa jenis tanaman. Bagian akhir dari tahap persiapan adalah merancang dan pembuatan percontohan sistem hidroponik DFT non listrik untuk disimulasikan pada tahap pelatihan lapangan.

Tahap kedua, yaitu sosialisai jadwal kegiatan dan materi yang disampaikan selama kegiatan PPM. Materi pendidikan dan pelatihan yang diberikan adalah pengenalan teknologi hidroponik, pompa Heron's Fountain, teknik penyemaian dan penanaman hidroponik, teknik penerapan teknologi, teknik pemeliharaan dan teknik panen tanaman hortikultura pada sistem hidroponik. Selain itu khalayak sasaran juga dibekali materi dasar pembukuan yang baik dalam pengelolaan usaha kecil. Setiap khalayak sasaran diberikan buku panduan singkat mengenai penerapan hidroponik non listrik. Bagian akhir dari kegiatan pendidikan dan pelatihan adalah mensimulasikan cara kerja hidroponik non listrik seperti yang dijelaskan pada sesi kelas dan tertera dalam buku panduan.

Tahap ketiga adalah subtitusi dan difusi Ipteks untuk khalayak sasaran. Hidroponik non listrik merupakan teknologi tepat guna berbasis ipteks baru yang dihasilkan dari modifikasi dan penggabungan teknologi hidroponik DFT dan pompa Heron's Fountain, perlakuan ini diistilahkan sebagai subtitusi Ipteks. Sementara difusi Ipteks merupakan serangkaian kegiatan yang menghasilkan produk bagi khalayak sasaran. Jumlah hidroponik DFT non listrik yang dibuat pada kegiatan ini sebanyak 5 unit. Pada tahap ini, tim pengabdian Universitas Bengkulu melakukan pendampingan kepada khalayak sasaran secara langsung dalam pembuatan, penerapan dan pemeliharaan sistem hidroponik dan pompa Heron's Fountain. Ukuran sistem disesuaikan dengan lokasi penempatan hidroponik (rumah anggota ibu PKK). Selain itu, tim pengabdian juga melakukan pendampingan secara langsung mengenai teknik menanam, memelihara hingga memanen hasil tanaman hortikultura yang menggunakan teknologi hidroponik.

\section{HASIL DAN PEMBAHASAN}

Kegiatan pendidikan, pelatihan dan pendampingan penerapan hidroponik DFT non listrik dilakukan pada Agustus 2018. Namun sebelum ketiga kegiatan itu dilaksanakan, beberapa waktu sebelumnya dilakukan beberapa rangkaian persiapan oleh tim pengabdian, yaitu pembuatan sistem hidroponik DFT non listrik dan penyemaian beberapa jenis tanaman hortikultura yang digunakan sebagai bahan tambahan pada kegiatan pelatihan dan pendampingan sesi lapangan. Proses pembuatan hidroponik DFT non listrik dan proses penyemaian ditunjukkan pada Gambar 3. Berbagai jenis tanaman yang disemai dan digunakan dalam kegiatan pengabdian ini seperti sawi Pokchoy, Sawi Manis, Kangkung, Bayam Merah, Bayam Hijau, Cabe Rawit, Tomat mini (cherry), Strowberry, dan daun Seledri. Simulasi keanekaragaman jenis tanaman ini dilakukan untuk menginformasikan kepada mitra 
mengenai apa saja tanaman hortikultura yang dapat dibudidayakan menggunakan sistem hidroponik. Media penyemaian benih menggunakan rock woll dan proses penyemaian dilakukan selama 8 hingga 10 hari.

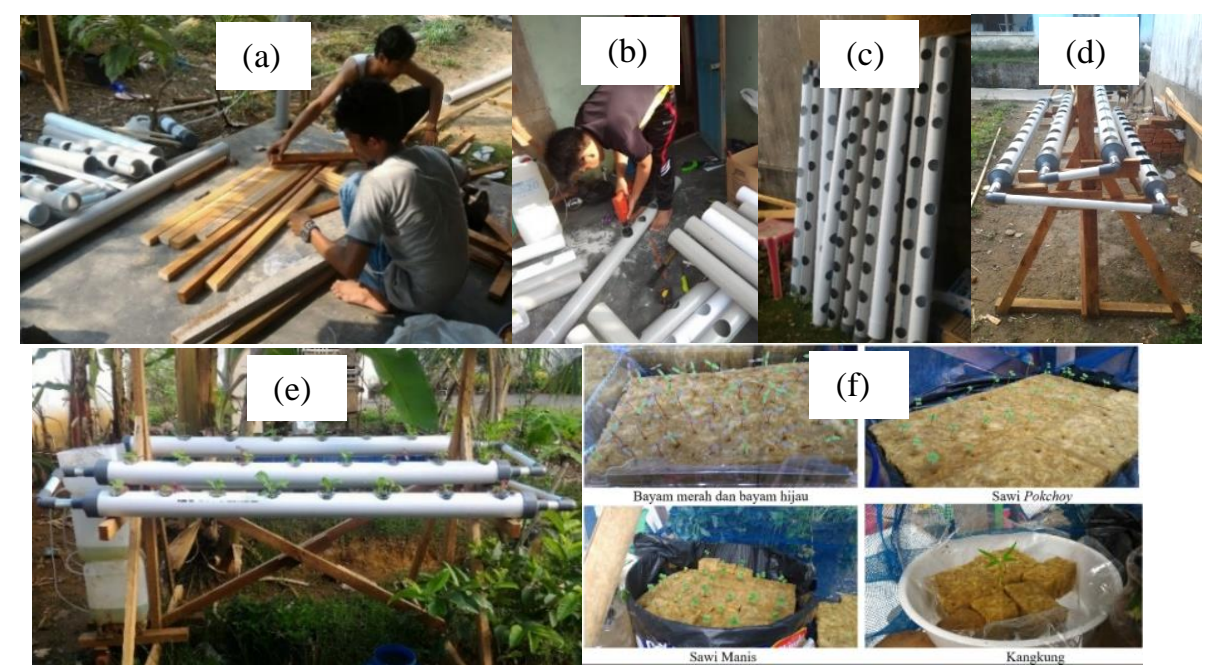

Gambar 3. (a) Proses pembuatan rak hidroponik; (b) proses pengeboran paralon; (c) wujud bangun sistem hidroponik dan pompa Heron's Fountain yang masih terpisah; (d) wujud penggabungan sistem hidroponik dan pompa Heron's Fountain Penyuluhan

Sesi kelas diisi dengan sambutan dan penyampaian materi singkat mengenai teknologi hidroponik, teknologi pompa Heron's Fountain dan penerapan keduanya. Selain menjelaskan cara membuat kedua sistem, pada sesi kelas juga diberi penjelasan bagaimana cara penyemaaian, perawatan dan pemanenan. Jumlah peserta yang mengikuti sosialisasi dan praktik lapangan sebanyak 14 orang dari 20 Ibu PKK yang diundang. Masing-masing peserta diberikan buku panduan singkat yang berjudul "Penerapan pompa tanpa listrik (Heron's Fountain) pada Hidroponik DFT (Deep Flow Technique) untuk Tanaman Hortikultura". Proses sosialisasi atau pelatihan sesi kelas ditunjukkan pada Gambar 4.
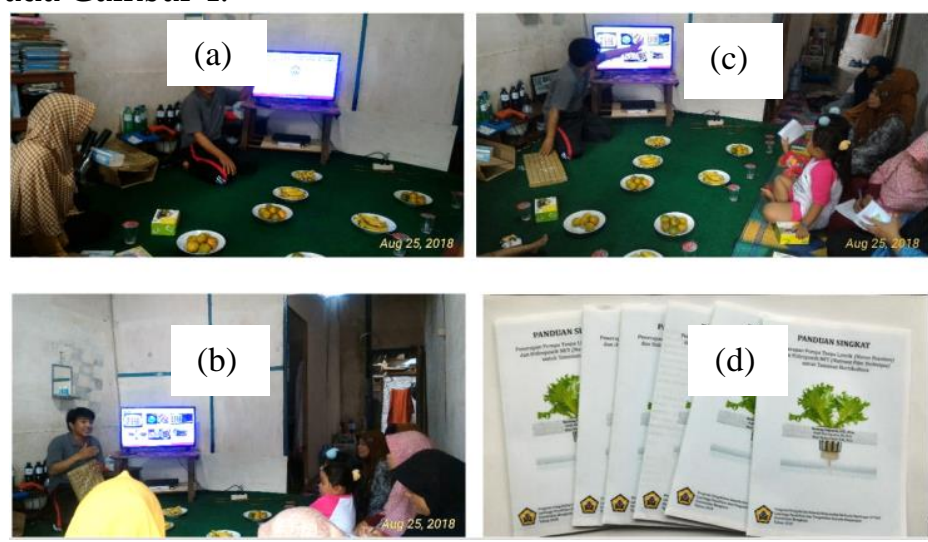

Gambar 4. (a), (b), dan (c) adalah dokumentasi proses pemaparan teori hidroponik dan pompa Heron's Fountain; (d). Panduan singkat hidroponik dan pompa Heron's Fountain untuk khalayak sasaran 


\section{Praktik Lapangan}

Sesi praktik lapangan lebih menekankan pada keterlibatan langsung khalayak sasaran untuk mencoba dan melakukan setiap tahapan praktik yang telah disusun oleh tim pengabdian. Kemampuan khalayak sasaran dalam menyelesaikan setiap tahapan dengan menjadi indikasi keberhasilan untuk sesi praktik lapangan. Selain memperkenalkan beberapa bahan yang digunakan, bagaimana cara membuat serta merakit kedua sistem menjadi bagian penting yang disampaikan kepada khalayak sasaran. Kemudian dilanjutkan dengan praktik bagaimana menyemai menggunakan rock woll, menanam, merawat tanaman pada hidroponik dan menggunakan pompa Heron's Fountain. Ukuran selang yang digunakan pada sistem pompa Heron's Fountain adalah $2 \mathrm{~mm}$ dan dirigen dengan volume 10 liter. Pompa Heron's Fountain yang dibuat dapat beroperasi rata-rata 45 menit. Hasil uji coba menunjukkan bahwa kadar nutrisi pada paralon terakhir (keempat) hanya berbeda 7\% dari kadar nutrisi pada paralon pertama. Dokumentasi yang diabadikan pada sesi praktik dilapangan ini ditunjukkan pada Gambar 5.
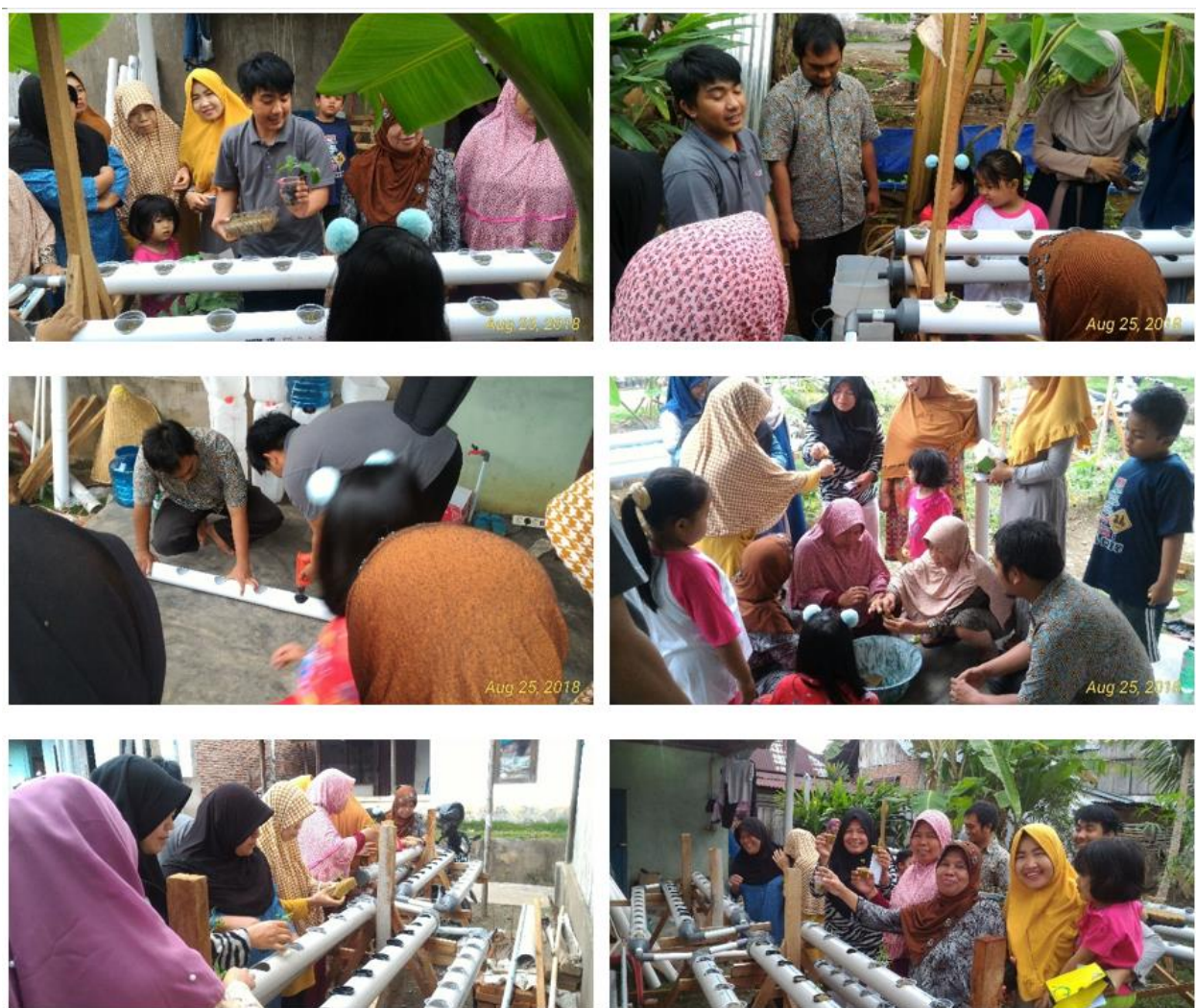

Gambar 5. Dokumentasi pada tahapan praktik di lapangan pada kegiatan

Pengabdian kepada masyarakat mengenai penerapan pompa Heron's Fountain pada sistem hidroponik

\section{Perawatan Tanaman Hidroponik}

Kegiatan perawatan merupakan tahap penting yang dilakukan pasca tahap penanaman. Lima unit sistem hidroponik telah diserahkan kepada mitra pada 11 September 2018. Tahap perawatan tanaman hidroponik dilakukan secara langsung oleh 
mitra secara mandiri dengan pendampingan oleh tim pengabdian. Proses moitoring dilakukan satu minggu sekali oleh ketua pengabdi untuk melihat perkembangan tanaman hidroponik yang dirawat oleh khalayak sasaran. Penggunaan nutrisi disesuaikan dengan petunjuk yang tertera pada kemasan pupuk. Selama proses perawatan tidak ditemukan kesulitan pada khalayak sasaran. Gambar 6a dan Gambar $6 \mathrm{~b}$ menujukkan dua dokumentasi pertumbuhan tanaman selama perawatan. Selain mengontrol tanaman dari nutrisi, hal lain yang dilakukan oleh mitra adalah perawatan tanaman dari hama seperti semut, kutu daun, belalang, jentik nyamuk dan pemberian dua naungan untuk mengurangi evaporasi dan stress pada tanaman akibat suhu terlalu panas (Mansyur dkk, 2014). Hama semut, kutu dan belalang disemprotkan dengan DuPont Lannate dan Exocet sementara hama jentik nyamuk diberikan butiran $A \beta T$ (Gambar 7b).
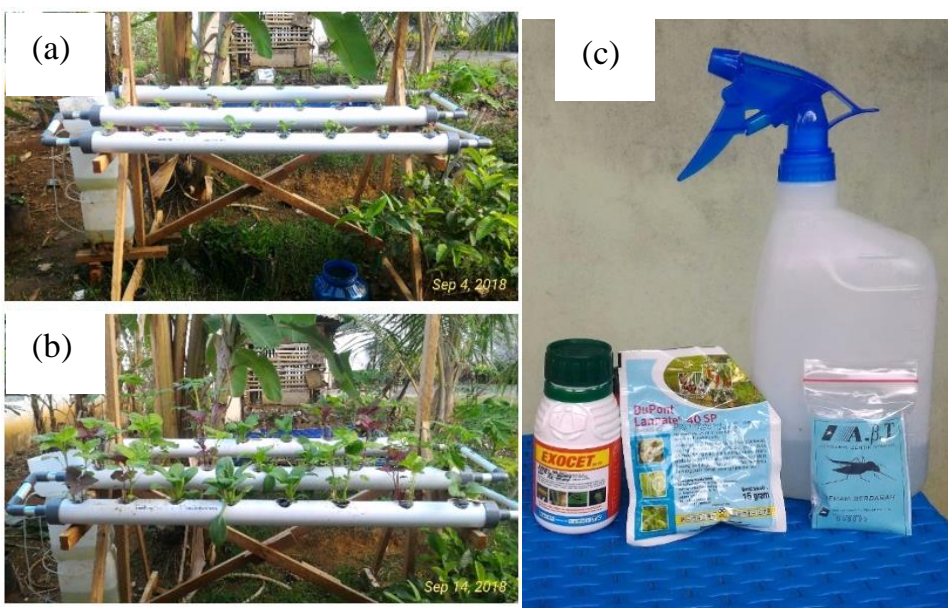

Gambar 6. Dokumentasi selama proses perawatan tanaman. (a) kenampakan tanaman hidroponik saat berusia 25 hari (dihitung dari masa penyemaian). (b) kenampakan tanaman hidroponik saat berusia 35 hari. (c). alat dan bahan pebasmi hama dan jentik nyamuk

\section{Pemanenan}

Setiap tanaman tumbuh secara optimal dan hasil panen lebih banyak dari perkiraan awal. Tanaman kangkung dan bayam dapat dipanen lebih awal yaitu saat tanaman berusia 7 minggu. Berbeda dengan sawi manis dan sawi Pak Choy, hanya efektif dipanen 1 kali saat tanaman berusia 10 minggu. Cara panen bayam dan kangkung dilakukan dengan memotong bagian tanaman. Setiap pemotongan, rumpun bayam dan kangkung akan tumbuh tunas baru dan dapat secara efektif dipanen hingga 4 (empat) kali pemanenan. Proses pemananenan oleh anggota khalayak sasaran didokumentasikan pada Gambar 7. 

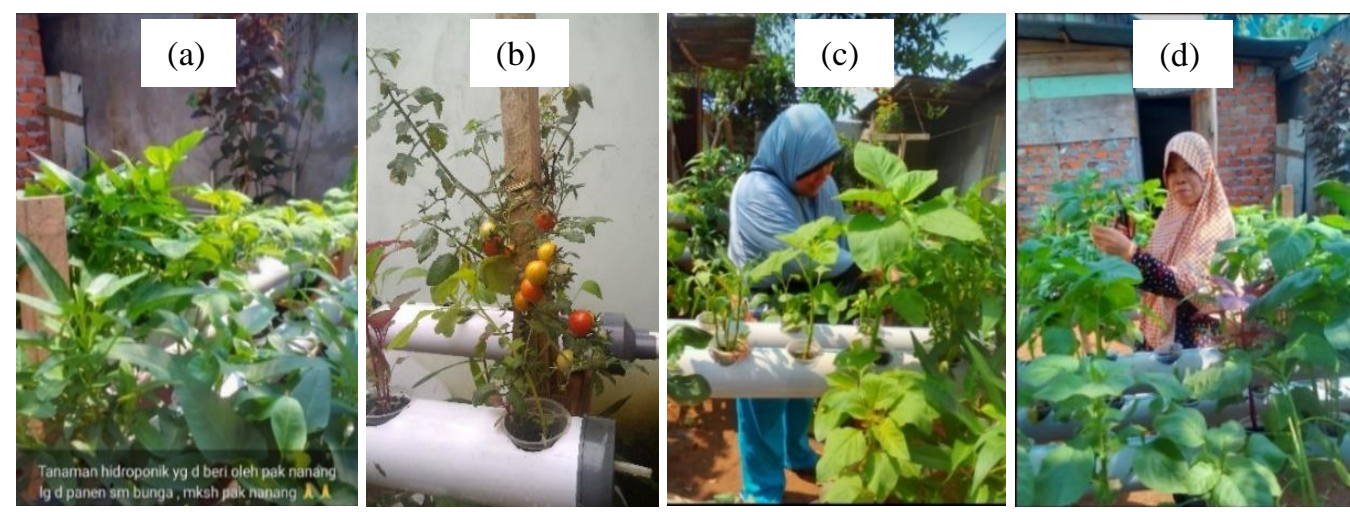

Gambar 7. Dokumentasi; (a) kondisi tanaman hortikultura sebelum usia 8 minggu;

(b) kenampakan tomat cherry yang sudah siap panen dan proses pemananenan tanaman hidroponik yang dilakukan oleh Ketua Ibu PKK; (c) dan anggotanya (d)

\section{Pembentukan Kelompok Usaha Tanaman Hortikultura}

Program pengabdian berbasis Iptek ini dinilai mampu memberikan dampak signifikan bagi mitra dalam memproduksi dan memanfaatkan hasil panen tanaman hortikultura untuk dikonsumsi sendiri. Kegiatan ini tidak hanya mampu menjadi solusi alternatif bagi pecinta bercocok tanam tanaman hortikultura, tetapi juga menjadi kegiatan positif sebagai upaya untuk pemenuhan kebutuhan akan sayur-sayuran atau mengurangi biaya pengeluaran untuk membeli sayuran di pasar.

Tabel 1. Analisis nilai ekonomis penerapan hidroponik DFT non listrik untuk produksi tanaman hortikultura

\begin{tabular}{|c|c|c|c|c|c|c|c|}
\hline $\begin{array}{c}\text { Jenis } \\
\text { Tanaman/. } \\
\text { Sayuran/unit }\end{array}$ & $\begin{array}{l}\text { Rata-rata } \\
\text { Konsumsi } \\
\text { sayuran/ } \\
\text { bulan/ } \\
\text { Rumah } \\
\text { Tangga }\end{array}$ & $\begin{array}{l}\text { Harga } \\
\text { Beli/ } \\
\text { bulan }\end{array}$ & $\begin{array}{l}\text { Jumlah } \\
\text { panen } \\
\text { minimal } \\
\text { /bulan/unit }\end{array}$ & $\begin{array}{l}\text { Hasil } \\
\text { panen } \\
\text { dalam } \\
\text { Rupiah }\end{array}$ & $\begin{array}{l}\text { Biaya } \\
\text { produksi/ } \\
\text { bulan/unit }\end{array}$ & $\begin{array}{l}\text { Rp yang } \\
\text { dihemat/ } \\
\text { bulan/unit }\end{array}$ & $\begin{array}{c}\text { Persentase } \\
\text { biaya yang } \\
\text { dihemat/ } \\
\text { bulan (\%) }\end{array}$ \\
\hline 1. Pok choy & $8.00 \mathrm{~kg}$ & 64.000 & $7.00 \mathrm{~kg}$ & 56.000 & 15.000 & 41.000 & 73.20 \\
\hline 2. Sawi Manis & $15.00 \mathrm{~kg}$ & 120.000 & $13.00 \mathrm{~kg}$ & 104.000 & 15.000 & 89.000 & 85.60 \\
\hline 3. Sawi pahit & $5.00 \mathrm{~kg}$ & 40.000 & $8.00 \mathrm{~kg}$ & 64.000 & 15.000 & 49.000 & 76.60 \\
\hline 4. Bayam & $10.00 \mathrm{~kg}$ & 50.000 & $9.00 \mathrm{~kg}$ & 45.000 & 15.000 & 30.000 & 66.70 \\
\hline 5. Kangkung & $16.00 \mathrm{~kg}$ & 90.000 & $15.50 \mathrm{~kg}$ & 60.000 & 12.000 & 63.000 & 84.00 \\
\hline
\end{tabular}

Pasca panen tahap pertama, tim pengabdian bersama mitra melakukan pertemuan kembali pada sesi kelas lanjutan. Tujuan dari sesi kelas lanjutan ini adalah merealisasikan rencana pembentukan kelompok usaha tanaman hortikultura menggunakan hidroponik bagi Ibu-Ibu PKK RT 12, Kelurahan Sukamerindu, Bengkulu. Bersama-sama telah disepakati bahwa pada tanggal 21 November 2019 kelompok usaha tani tanaman hortikultura Ibu-ibu RT 12, Kelurahan Sukamerindu, Kota Bengkulu diberi dengan nama Kelompok Usaha "Berkah Maju". Kelompok Usaha Berkah Maju beranggotakan 20 orang yang terdiri dari 1 orang ketua, 1 orang Bendahara, 1 orang Sekretaris dan 17 orang anggota. Kelompok usaha tani "Berkah Maju” ini didirikan atas dasar rencana yang telah disepakati bersama mitra dan atas dasar hasil analisis perkiraan nilai ekonomis penerapan teknologi hidroponik DFT non listrik dalam menanam tanaman hortikultura. Proses analisis ini dilakukan pada tahap penanaman 
kembali (tahap kedua) dimana masing-masing unit hidroponik ditanam tanamanan hortikultura sejenis. Proses penanaman lanjutan ini tetap didampingi oleh tim pengabdian. Adapun sebaran perkiraan nilai ekonomis sebelum dan sesudah menggunakan teknologi hidroponik DFT bagi mitra ditunjukkan pada Tabel 1.

Berdasarkan Tabel 1, secara umum persentase biaya yang dihemat perbulan antara membeli sayuran di pasar dan produksi sendiri menggunakan hidroponik DFT non listrik adalah diatas $66 \%$. Persentase biaya yang dihemat tinggi terhitung pada produksi sawi manis $(85.6 \%)$ dan kangkung $(84 \%)$. Perolehan ini memberikan dampak positif bagi mitra, sehingga mampu menumbuhkan kembali semangat dalam memproduksi tanaman hortikultura dan menjadi rencana kelompok usaha bagi Ibu-Ibu PKK yang berkelanjutan.

\section{Monitoring dan Evaluasi}

Monitoring dan evaluasi (Monev) merupakan salah satu kegiatan yang tersusun dalam rangkaian kegiatan pengabdian kepada masyarakat berbasis IPTEKS. Kegiatan MonEv pada tim pengabdian dilakukan pada tanggal 1 September 2019. Kegiatan Monev dihadiri oleh tim reviewer, tim LPPM, Tim Pengabdian, Ketua Ibu PKK, Ketua RT 12 dan beberapa warga RT 12 kelurahan Sukamerindu. Kegiatan MonEv ini terdiri dari sesi wawancara dan sesi uji instrumen serta perlengkapan lainnya yang digunakan pada proses pengabdian kepada khalayak sasaran. Dokumentasi kegiatan MonEv tersebut ditunjukkan pada Gambar 8.

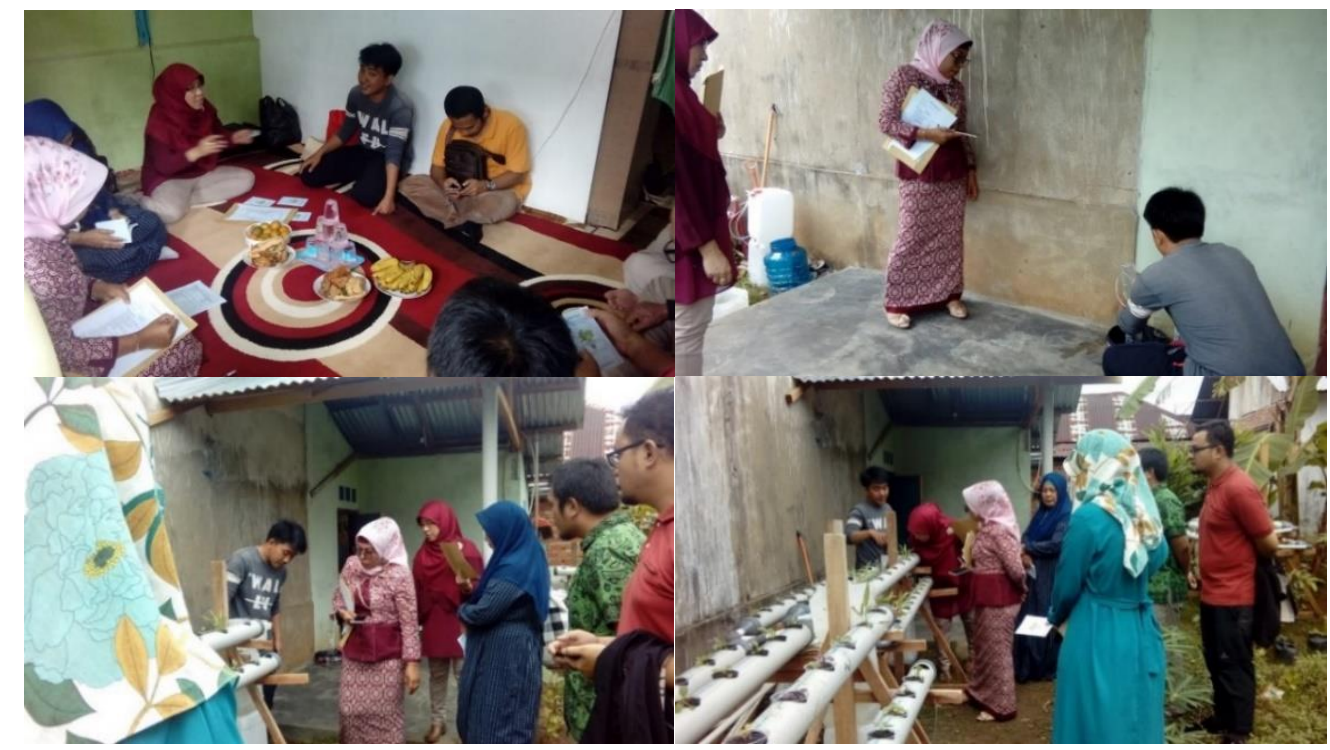

Gambar 8. Dokumentasi proses Monitoring dan evaluasi lapangan kegiatan PPM berbasis IPTEKS UNIB 2018

\section{SIMPULAN}

Penerapan pompa Heron Fountain untuk hidroponik sisten DFT terbukti efektif dalam melakukan sirkulasi nutrisi terputus bagi tanaman hidroponik. Pompa Heron's Fountain yang dibangun dapat bekerja secara termporari dengan durasi 45 menit (10 
liter). Waktu ini dianggap cukup dalam mensirkulasikan nutrisi bagi tanaman hidroponik yang dibuktikan dengan kualitas tanaman yang sama baik di paralon pertama maupun di paralon terakhir (ke-4). Semua tanaman tumbuh dengan optimal dan hasil panen lebih banyak dari perkiraan awal. Masa tanam hingga panen menggunakan teknologi hidroponik dan pompa Heron's Fountain terbilang cukup singkat lebih kurang selama 2,5 bulan. Persentasi biaya yang dihemat perbulan antara membeli sayuran di pasar dan produksi sendiri menggunakan hidroponik DFT non listrik adalah diatas 66\%. Penerapan teknologi hidroponik DFT non listrik memberikan manfaat yang signifikan bagi mitra hingga terbentuknya kelompok usaha tani bagi ibuIbu PKK yang diberi nama "Berkah Maju" untuk pengembambangan lebih lanjut.

\section{REFERENSI}

Anas, D. S. (2013). Bahan ajar mata kuliah dasar-dasar hortikultura. Bogor: Departemen Agronomi dan Hortikultura, Fakultas Pertanian, IPB, Bogor.

Atmaja, F. D. (2009). Analisis keseimbangan panas dan bak penanaman dalam sistem hidroponik deep flow technique (DFT). Bogor: Fakultas Teknologi Pertanian. Institut Pertanian Bogor.

BPS. (2013). Survei Pertanian Hortikultura (SPH) BPS Provinsi Bengkulu. Retreived June 1, 2018 from https://bengkulu.bps.go.id/subject/55/hortikultura.html.

Georgescu, A. M., Georgescu, S. C., \& Stroia, L. (2013). Heron's fountain demonstrator. Revista Romana de Inginerie Civila, 5(2), 87-94.

Igbal, M. (2006). Penggunaan pupuk mejamuk sebagai sumber hara pada budidaya bayam secara hidroponik dengan tiga cara fertigasi. Bogor: Fakultas Pertanian IPB.

Kezerashvili, \& Sapozhnikov. (2016). Magic Heron. Presented: North East Regional Conference of the American Association of Physics Teachers at Princeton University.

Mansyur, A. N., Triyono, S., \& Tusi, A. (2014). Pengaruh naungan terhadap pertumbuhan sawi (brassica juncea 1.) pada sistem hidroponik DFT (deep flow technique). Jurnal Teknik Pertanian Lampung, 3(2), 103-110.

Ningrum, D. Y., Triyono, S., \& Tusi, A. (2014). Pengaruh lama aerasi terhadap pertumbuhan dan hasil tanaman sawi (Brassica juncea L.) pada hidroponik DFT (Deep flow technique). Jurnal Teknik Pertanian Lampung, 3(1), 83-90.

Purnomo, A. (2006). Oksigen terlarut (DO) 1 dan 2. Retrieved June 5, 2019 from http://belajarhidroponik.blogspot.com/2006/10/oksigen-terlarut-do-1.html

Roidah, I. S. (2015). Pemanfaatan lahan dengan menggunakan sistem hidroponik. Jurnal Bonorowo, 1(2), 43-49. 


\section{Copyright and License}

This is an open access article distributed under the terms of the Creative Commons Attribution 4.0 International License, which permits unrestricted use, distribution, and reproduction in any medium, provided the original work is properly cited.

(c) 2020 Nanang Sugianto, Irkhos, Supiyati, Helfi Eka Saputra.

Published by LP3M of Universitas Mathla'ul Anwar Banten in collaboration with the Asosiasi Jurnal Pengabdian Kepada Masyarakat (AJPKM) 